RESEARCH / INVESTIGACIÓN

\title{
Characteristics and quality of gray water and the possibility of reuse for irrigation purposes from the houses of some areas of the left side of the city of Mosul
}

Safa Arshed Saadoon, Ayad Fadeel Qasim

DOl. 10.21931/RB/2021.01.04.12

Abstract: The research dealt with assessing the quality of gray water generated from houses in some areas of the left side of the city of Mosul and determining the suitability of reusing it for irrigation; for this purpose, 90 samples of gray water were collected from fifteen neighborhoods of the left side for a period of six months during the period from November 2020 to April 2021. The research aims to conduct a monthly study to assess the quality and suitability of gray water for irrigation by conducting physical, chemical, and biological tests for gray water generated from houses Where the values of E.C. ranged (751-1621) $\mu$ S/ $\mathrm{cm}$ and T.D.S. (483-684) mg/L, and pH ranged (6.3-8.2), and the concentration of sodium ions ranged between (7.8-147) mg/L as for the concentration of C.O.D. (Chemical Oxygen Demand) ranged between (69-200) mg/L While the C.O.D. values ranged between (69-200) $\mathrm{mg} / \mathrm{L}$, The S.A.R. values were between (0.18-2.98) meq/L, and the phosphate ions values ranged between (0.25-3.7) $\mathrm{mg} / \mathrm{L}$; finally, the average of fecal coliform bacteria was $(0.0-4) \times 10^{5} / 100 \mathrm{ml}$. The study concluded that the water was classified under the category (C3-S1) high salinity - low sodium, which is suitable for irrigation of plants that are well tolerant to salinity and is suitable for use in soils that do not contain complex layers that prevent leaching because these soils will need to be washed when irrigated with this water. This study recommended diluting gray water by mixing it with fresh water and using it for irrigation.

Key words: Characteristics, Greywater, Reuse, irrigation, S.A.R. (Sodium adsorption ratio), C.O.D.

\section{Introduction}

Iraq has suffered from water scarcity in recent years, and this problem has steadily been exacerbated with the increase in the population. The per capita water supply will decrease annually unless alternative water sources are provided. This, in turn, pushes decision-makers and technicians to search for unconventional water sources, including gray water and treated wastewater for irrigation in environmentally safe ways, and the problems of the agricultural sector under the current water shortage conditions are a difficult task for decision-makers in Iraq due to the low share of the agricultural sector of water and the increased demand for water for other sectors. Therefore, it is necessary to reuse all the available water resources, including low-quality water sources, to face these problems ${ }^{1}$.

Contaminated water sources such as gray water and treated wastewater are used for irrigation purposes in the dry and semi-arid countries of the region because of the lack of water in them, and their use reduces the demand for freshwater sources. The use of this type of water is either directly, that is, by adding this water to the soil directly, provided that not to be stored for a long time before use or indirectly by being thrown into rivers and streams, gray water is an essential source of water that can be used to irrigate crops and trees It is divided into two types: the first is called (Blackwater); it includes water that is discharged from the toilet; this type of water contains a large number of pathogens. It also contains a high concentration of organic matter, in addition to containing nitrogen and phosphorous ${ }^{2}$

The second type is called (Gray water); it's the water collected from sewage discharge of cloth washers, showers, bathtubs, and sinks; it is called gray water because it is left for an extended period, its color will change to gray ${ }^{3,4}$.

Gray water flowing from showers, washing machines, and bathroom sinks represents more than $60 \%$ of the total domes- tic wastewater, indicating that gray water is an attractive source for reuse for irrigation purposes if it is properly exploited and used on correct environmental bases ${ }^{5}$.

\section{Materials and methods}

\section{Study Area}

The study area included several neighborhoods on the left side of the city of Mosul, and its included fifteen neighborhoods on the left side, which are:( Al-Muhandiseen, Al-Hadbaa, ALZiraal, Al-Mazarie, AL-Qadisiyah 1, Al-Kafaat 1, AL-Shurta, AL-Zuhour, AL-Muthanna, Al-Noor, Al Baladyat, AL-Qahira, AL-Zahraa, Sumer, Aden). These areas are highly populated. The coordinates of the studied areas were fixed using the G.P.S. of the google earth program, as shown in table (1).

\section{Sample collection}

Water samples were collected from fifteen neighborhoods of Mosul from the left side of the city in the study area from November (2020) to April (2021) per month. The greywater samples were collected from the gray water drainage point of each house to conduct physical and chemical tests by using sterile polyethylene bottles with a capacity of $250 \mathrm{ml}$, and samples for bacterial tests were collected using sterilized bottles with sterilizers at a pressure of 1.5 pounds and degrees $(121)^{\circ} \mathrm{C}$ for 15 minutes. The samples were kept in a refrigerated container away from light until they reached the laboratory ${ }^{6}$.

\section{Field tests}

It included measuring temperature using an alcohol ther- 


\begin{tabular}{|c|c|c|c|}
\hline \multirow{2}{*}{\multicolumn{2}{|c|}{ Areas and locations }} & \multicolumn{2}{|c|}{ Coordinates } \\
\hline & & \multirow{2}{*}{$\frac{\mathrm{N}}{36^{\circ} 22^{\prime} 05.6^{\prime \prime} \mathrm{N}}$} & \multirow{2}{*}{$\begin{array}{c}\mathrm{E} \\
43^{\circ} 08^{\prime} 08.9^{\prime \prime} \mathrm{E}\end{array}$} \\
\hline Al-Muhandiseen & 1 & & \\
\hline Al-Hadbaa & 2 & $36^{\circ} 23^{\prime} 42.8^{\prime \prime} \mathrm{N}$ & $43^{\circ} 09^{\prime} 10.7^{\prime \prime} \mathrm{E}$ \\
\hline AL-ZiraaI & 3 & $36^{\circ} 21^{\prime} 16.6^{\prime \prime} \mathrm{N}$ & $43^{\circ} 08^{\prime} 37.7^{\prime \prime E}$ \\
\hline Al-Mazarie & 4 & $36^{\circ} 19^{\prime} 39.3^{\prime \prime} \mathrm{N}$ & $43^{\circ} 10^{\prime} 34.9^{\prime \prime} \mathrm{E}$ \\
\hline AL-Qadisiyah 1 & 5 & $36^{\circ} 22^{\prime} 32.9^{\prime \prime} \mathrm{N}$ & $43^{\circ} 11 ' 25.1^{\prime \prime E}$ \\
\hline Al-Kafaat 1 & 6 & $36^{\circ} 22^{\prime} 52.2^{\prime \prime} \mathrm{N}$ & $43^{\circ} 09^{\prime} 20.4^{\prime \prime} \mathrm{E}$ \\
\hline AL-Shurta & 7 & $36^{\circ} 22^{\prime} 36.0^{\prime \prime} \mathrm{N}$ & $43^{\circ} 08^{\prime} 14.2^{\prime \prime} \mathrm{E}$ \\
\hline AL-Zuhour & 8 & $36^{\circ} 22^{\prime} 54.5^{\prime \prime} \mathrm{N}$ & $43^{\circ} 11 ' 11.7 " \mathrm{E}$ \\
\hline AL-Muthanna & 9 & $36^{\circ} 22^{\prime} 15.8^{\prime \prime} \mathrm{N}$ & $43^{\circ} 10^{\prime} 28.6^{\prime \prime E}$ \\
\hline Al-Noor & 10 & $36^{\circ} 21^{\prime} 58.0^{\prime \prime} \mathrm{N}$ & $43^{\circ} 11^{\prime} 06.3^{\prime \prime} \mathrm{E}$ \\
\hline Al Baladyat & 11 & $36^{\circ} 23^{\prime} 07.4^{\prime \prime} \mathrm{N}$ & $43^{\circ} 09^{\prime} 44.5^{\prime \prime} \mathrm{E}$ \\
\hline AL-Qahira & 12 & $36^{\circ} 23^{\prime} 50.9^{\prime \prime} \mathrm{N}$ & $43^{\circ} 11 ' 29.5 " \mathrm{E}$ \\
\hline AL-Zahraa & 13 & $36^{\circ} 23^{\prime} 05.1^{\prime \prime} \mathrm{N}$ & $43^{\circ} 12^{\prime} 28.9^{\prime \prime} \mathrm{E}$ \\
\hline Sumer & 14 & $36^{\circ} 18^{\prime} 00.9^{\prime \prime} \mathrm{N}$ & $43^{\circ} 12^{\prime} 17.9^{\prime \prime} \mathrm{E}$ \\
\hline Aden & 15 & $36^{\circ} 21^{\prime} 07.0^{\prime \prime} \mathrm{N}$ & $43^{\circ} 12^{\prime} 46.7^{\prime \prime} \mathrm{E}$ \\
\hline
\end{tabular}

Table 1. The names of the areas and their locations. mometer, measured in degrees Celsius, measuring total dissolved solids by T.D.S meter in $\mathrm{mg} / \mathrm{L}$, electrical conductivity in $\mu \mathrm{S} / \mathrm{cm}$ by using E.C. meter, and measuring the acidity function using a $\mathrm{pH}$ meter.

\section{Laboratory tests}

It included measurement of the chemical oxygen demand (C.O.D.) by Closed Reflux method, determination of sodium ion using the Flame photometer, determination of Phosphate ion by Stannous Chloride method, counting the number of fecal coliform bacteria by (Multiple Tube Method) and Most Probable Number method ${ }^{6}$ and finally calculation of the sodium adsorption ratio (S.A.R.). The chemical tests were conducted at the College of Environmental Engineering, while the biological tests were conducted at the College of Environmental Sciences and Technologies at the University of Mosul.

\section{Results}

The components of gray water depend mainly on the quality of the available water sources and family habits when cleaning and preparing food?

\section{Physical Characteristics}

\section{Temperature}

Temperature is one of the critical environmental factors affecting the qualitative characteristics of water, as it affects water's chemical and physical reactions ${ }^{8}$. Table (2) and Figure (1) show that the temperature of the studied water samples fluctuated during the study period. The temperature range $(15-32.3)^{\circ} \mathrm{C}$ and averaged $(20-23.8)^{\circ} \mathrm{C}$ the highest temperature was in the site (8) in November 2020, and the lowest was in the site (5) in January 2021. This difference is attributed to the use of warm water when preparing food and for cleaning ${ }^{9}$.

\section{Electrical Conductivity and Total Dissolved Solids (EC\&T.D.S)}

Electrical conductivity is a measure of the concentration of dissolved anions and cations. Electrical conductivity is used as an indicator of the water content of dissolved solids of salts and minerals. It can contain low concentrations of dissolved organic materials in water. The total dissolved solids are used as a primary indicator of water quality measurement ${ }^{10,11}$.

The results are shown in table (2) and Figure (2) indicate

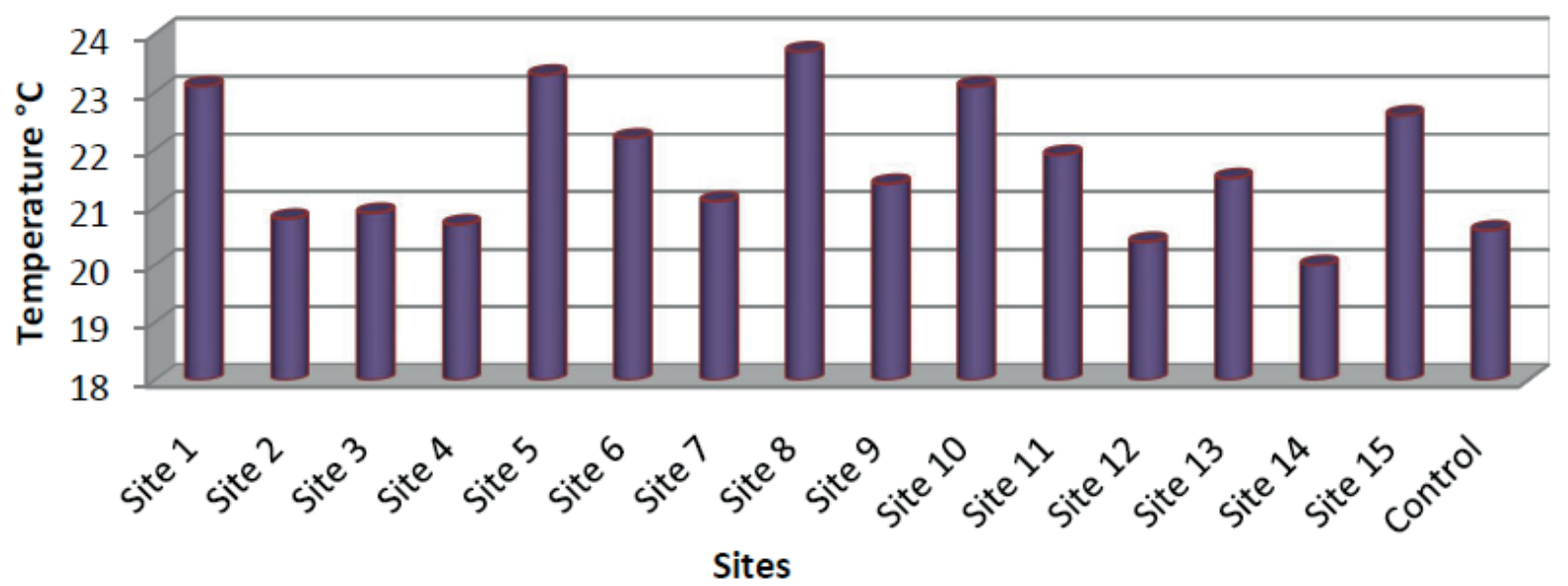

Figure 1. Shows the average temperatures of the study areas. 


\begin{tabular}{|c|c|c|c|c|c|c|c|c|c|}
\hline $\begin{array}{c}\text { Parameter } \\
\text { Sites }\end{array}$ & $\begin{array}{c}\text { Temp }{ }^{\circ} \mathrm{C} \\
.\end{array}$ & pH & $\begin{array}{c}\text { E C } \\
\mu \mathrm{S} / \mathrm{cm}\end{array}$ & $\begin{array}{l}\text { T.D.S. } \\
\text { mg/L }\end{array}$ & $\begin{array}{l}\mathrm{Na}^{+2} \\
\mathrm{mg} / \mathrm{L}\end{array}$ & $\begin{array}{c}\text { C.O.D. } \\
\mathrm{mg} / \mathrm{L}\end{array}$ & $\begin{array}{l}\mathrm{PO}_{4}^{-3} \\
\mathrm{mg} / \mathrm{L}\end{array}$ & $\begin{array}{l}\text { S.A.R. } \\
\text { meq/L }\end{array}$ & $\begin{array}{c}\text { Fecal } \\
\text { coliform } \\
\times 10^{5} / 100 \mathrm{ml}\end{array}$ \\
\hline Control & 20.6 & 7.3 & 499 & 247 & 6 & 4.7 & 0.09 & 0.2 & Nill \\
\hline Site 1 & 23.1 & 7.4 & 1083 & 478 & 49 & 97 & 1.1 & 1.2 & Nill \\
\hline Site 2 & 20.8 & 7.2 & 1038 & 427 & 38 & 97 & 0.7 & 1 & Nill \\
\hline Site 3 & 20.9 & 7.4 & 986 & 452 & 44 & 92 & 1.4 & 1.1 & 1 \\
\hline Site 4 & 20.7 & 7.2 & 981 & 442 & 36 & 95 & 0.5 & 0.9 & 0.5 \\
\hline Site 5 & 23.3 & 7.5 & 106 & 512 & 78 & 105 & 0.8 & 1.8 & 0.7 \\
\hline Site 6 & 22.2 & 7.2 & 999 & 468 & 83 & 115 & 1.4 & 1.9 & Nill \\
\hline Site 7 & 21.1 & 7.3 & 944 & 436 & 34 & 117 & 0.8 & 0.8 & 0.5 \\
\hline Site 8 & 23.7 & 7.3 & 922 & 430 & 35 & 90 & 2 & 0.8 & 1.5 \\
\hline Site 9 & 21.4 & 6.8 & 927 & 430 & 32 & 85 & 0.9 & 0.8 & 1.5 \\
\hline Site 10 & 23.1 & 7.5 & 883 & 421 & 49 & 94 & 1.1 & 1.2 & 1 \\
\hline Site 11 & 21.9 & 7.6 & 965 & 452 & 36 & 99 & 1 & 0.8 & Nill \\
\hline Site 12 & 20.4 & 7.3 & 996 & 448 & 40 & 93 & 0.6 & 1 & 1 \\
\hline Site 13 & 21.5 & 7.5 & 917 & 425 & 67 & 98 & 1 & 1.7 & 0.7 \\
\hline Site 14 & 20 & 7.1 & 962 & 432 & 41 & 86 & 1.6 & 1.1 & 1 \\
\hline Site 15 & 22.6 & 7.4 & 994 & 470 & 32 & 121 & 0.8 & 0.8 & 1 \\
\hline
\end{tabular}

Table 2. Physical and chemical, and biological characteristics of Mosul city greywater.

that there is a significant fluctuation in the electrical conductivity values, and the values ranged between (751-1621) $\mu \mathrm{S} / \mathrm{cm}$ and averaged (883-1083) $\mathrm{SS} / \mathrm{cm}$ the lowest value was in site (10) In November 2020 and the highest value was in site (2) in January 2021.The T.D.S. values shown in table (2) its ranged between (483-684) mg/l and averaged (421-512) mg/l where the highest value was in site (1) in November 2020 and the lowest value was in site (10) in December 2020 This increase is due to the presence of salts that are resulting from detergents such as sodium chloride and nitrates and phosphates, and the old water pipes contribute to increasing the electrical conductivity due to pipes rusting and then these materials leaching to the gray water ${ }^{12,13}$

The Gray water in this study was classified according to the average of electrical conductivity values within the category of highly saline water $\left(\mathrm{C}_{3}\right)$ according to the classification of the American Salinity Laboratory.

\section{Chemical Characteristics}

\section{$\mathrm{pH}$}

The $\mathrm{pH}$ function expresses the activity and concentration of the hydrogen ion in water, the $\mathrm{pH}$ in the gray water depends mainly on the $\mathrm{pH}$ and alkaline of the water supply sources. The $\mathrm{pH}$ of gray water is directly related to certain chemicals such as softeners, bleaching agents, and disinfectants ${ }^{11}$. The results shown in table (2) and Figure (3) showed that the $\mathrm{pH}$ values ranged between (6.3-8.2) and averaged (6.88-7.62), the highest value of the $\mathrm{pH}$ was in December 2020, January, February, and April 2021 in each of the site $(3,4,7,10,11)$ while the lowest value was in March 2021 in site (4) and the pH of tap water was (7.30). Most of the samples tended to be alkaline this is due to the presence of alkaline substances used in detergents, this is due to the presence of alkaline substances used in detergents such as sodium hydroxide-based, where it was found that the main chemical components present in gray water are generated due to the use of these detergents in cleaning or washing activities. Detergents consist of surfactant active substances that act as the primary active agent in most cleaning products ${ }^{14}$. in general, the values of the $\mathrm{pH}$ function for all areas were within the limits of international standards allowed for irrigation.

\section{Sodium ions}

The results are shown in table (2), and Figure (4) indicate that the concentrations of sodium ions ranged between (7.8$147) \mathrm{mg} / \mathrm{l}$ at an average of (32.1-83.5) $\mathrm{mg} / \mathrm{l}$. The highest value was in site(13) in November 2020 while The lowest value was in site (15) in February 2021, This rise is attributed to the fact that soap and detergents contain sodium salts.15 and the average values of sodium in tap water were (6.5) $\mathrm{mg} / \mathrm{h}$.

\section{Phosphate ion}

The results of the current study showed that phosphate concentrations ranged between (0.25-3.7) $\mathrm{mg} / \mathrm{L}$ with an average of $(0.5-2.1) \mathrm{mg} / \mathrm{L}$, where the highest value was in site (14) in November 2020, while the lowest value was in site (11) in January 2021, The reason for these high values is due to the use of detergent products containing a high percentage of phosphates $^{15}$.

\section{Chemical Oxygen Demand (C.O.D.)}

The results of the study shown in table (2) and Figure (6) indicated that the C.O.D. concentrations were high, ranging between (69-200) $\mathrm{mg} / \mathrm{L}$ and an average of (82.5-121.3) $\mathrm{mg} / \mathrm{L}$. This rise is due to the presence of Biodegradable and non-biodegradable organic matter and detergents. Produced from washing powders and dishwashing liquids, in addition to the presence of anionic surfactants and other oil substances in gray water samples, which increase the concentration of $\mathrm{COD}^{16}$.

\section{Sodium adsorption ratio (S.A.R.)}

The sodium adsorption ratio represents the inverse relationship between sodium ions and calcium and magnesium 
ions and the degree of the tendency of irrigation water to enter into cation exchange reactions in the soil ${ }^{17-19}$.

The results shown in table (2) and Figure (7) showed that the values ranged between $(0.18-2.98) \mathrm{meq} / \mathrm{L}$, where the lowest value was in (15) in February 2021, while the highest value was in (10) during November 2020, The reason for the decrease is due to the high concentrations of calcium and magnesium ions compared to sodium ions ${ }^{20}$, and when comparing the results with the certified International Classifications for Irrigation The (S.A.R.) values of gray water for this study were within the S1 category, meaning that the water is of good quality for irrigation and there is no problem to affect the permeability and filtration ${ }^{21}$.

\section{Biological Characteristics}

\section{Fecal Coliform Bacteria (FC)}

It is a branched group of Total Coliform bacteria that is naturally present in huge numbers in the intestines of humans and warm-blooded animals, and the presence of these bacteria in the water is evidence of water contamination with feces ${ }^{22,23}$

The results are shown in table (2) and Figure (9) indica- te that the number of fecal coliform bacteria ranged between $(0.0-4) \times 10^{5} / 100 \mathrm{ml}$, where the highest value was in site (13) and (5) in December 2020 and February 2021 respectively when the lowest value was in most of the gray water samples in the studied areas. The contamination of some water samples in this study is usually attributed to largely associated with poor personal hygiene and disposal of grey water that contains washed nappies or as a result of washing shoes, or due to the presence of children under the age of 12 years in the house, or it may result from washing the raw meat ${ }^{24,25}$.

\section{Conclusions}

There is an increase in some studied parameters such as E.C., T.D.S., C.O.D., and sodium ions. Gray water in this study was classified according to the E.C. values within the category of high salinity water $\left(\mathrm{C}_{3}\right)$ according to the classification of the American Salinity Laboratory, where it is recommended to use it for irrigation of crops that tolerate high salinity. The S.A.R. values for all studied samples were within the appropriate Limits for irrigation and were classified within the S1 category, meaning that the water has a good quality for irrigation.

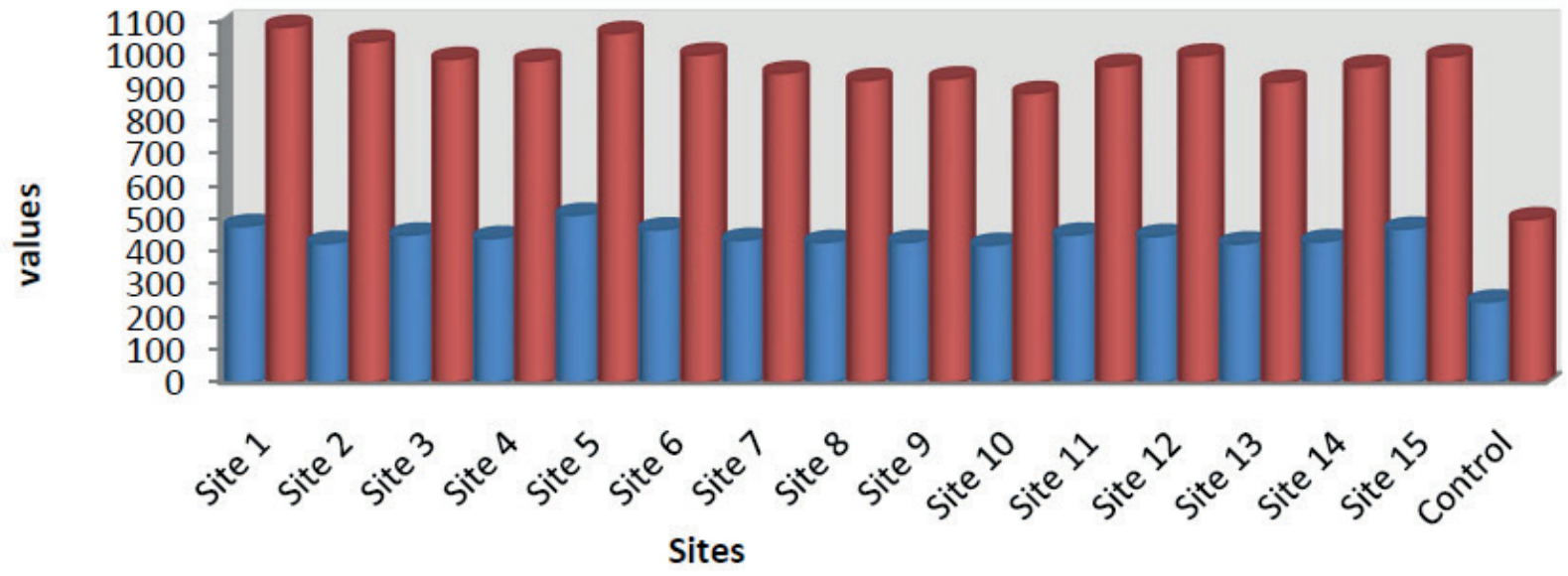

Figure 2. Average values of electrical conductivity and total dissolved solids concentration.

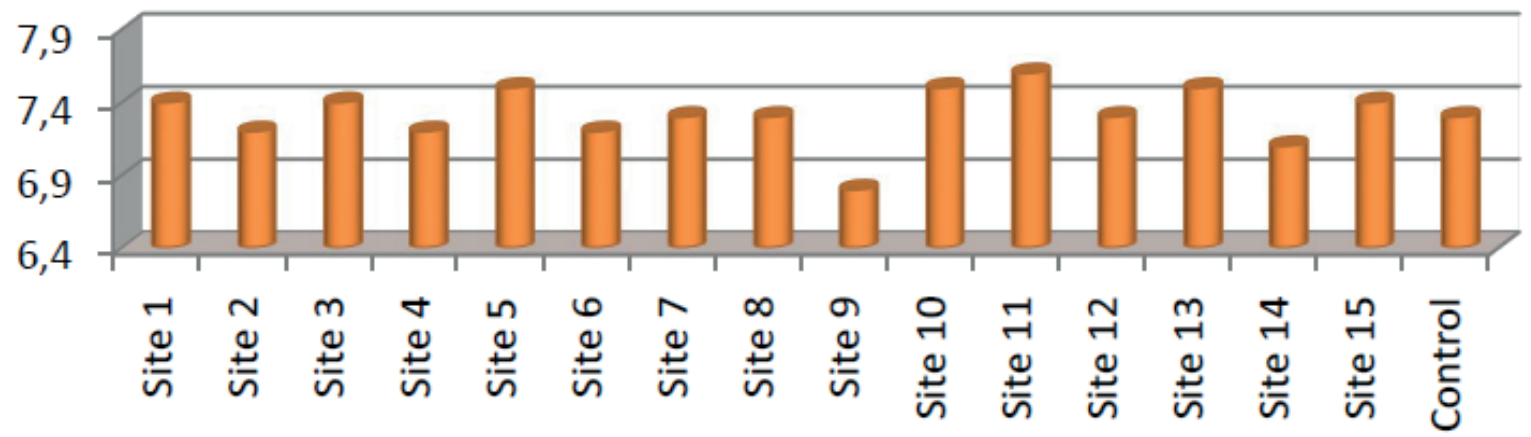

Sites

Figure 3. Shows the average values of the $\mathrm{pH}$ in the studied areas. 


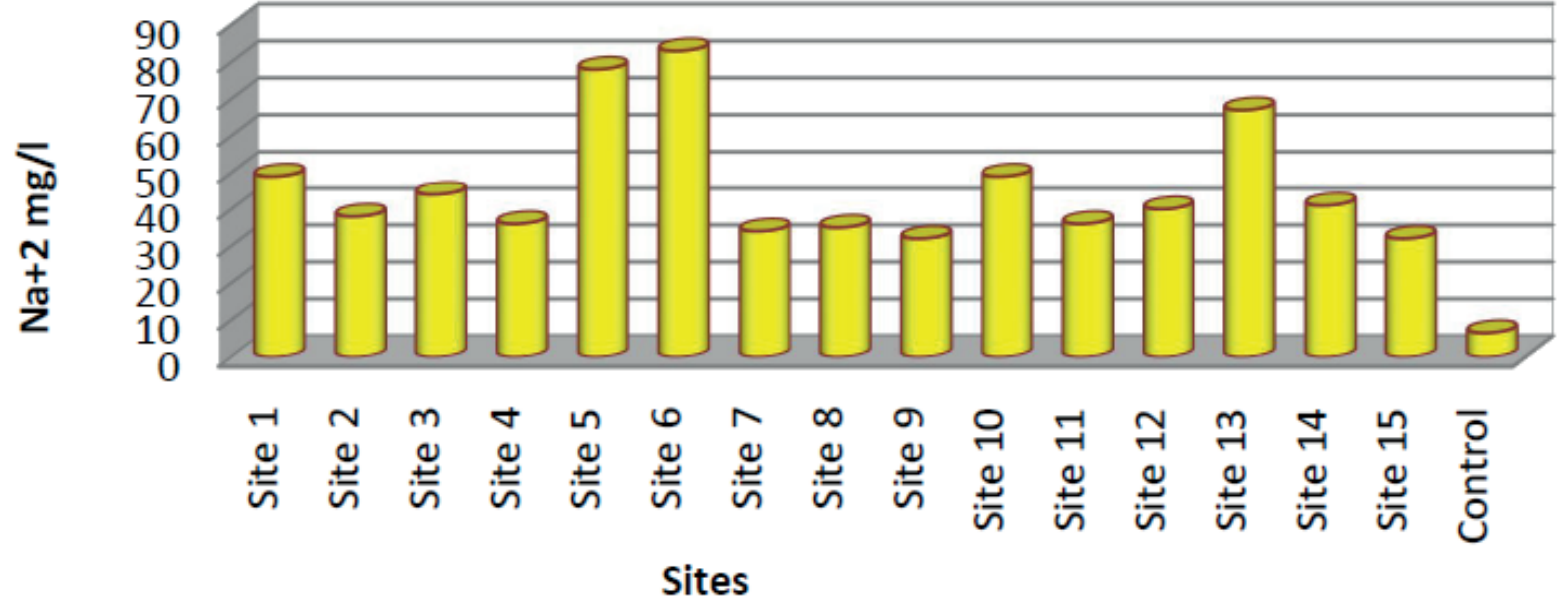

Figure 4. Shows the average concentration of sodium ions of samples.

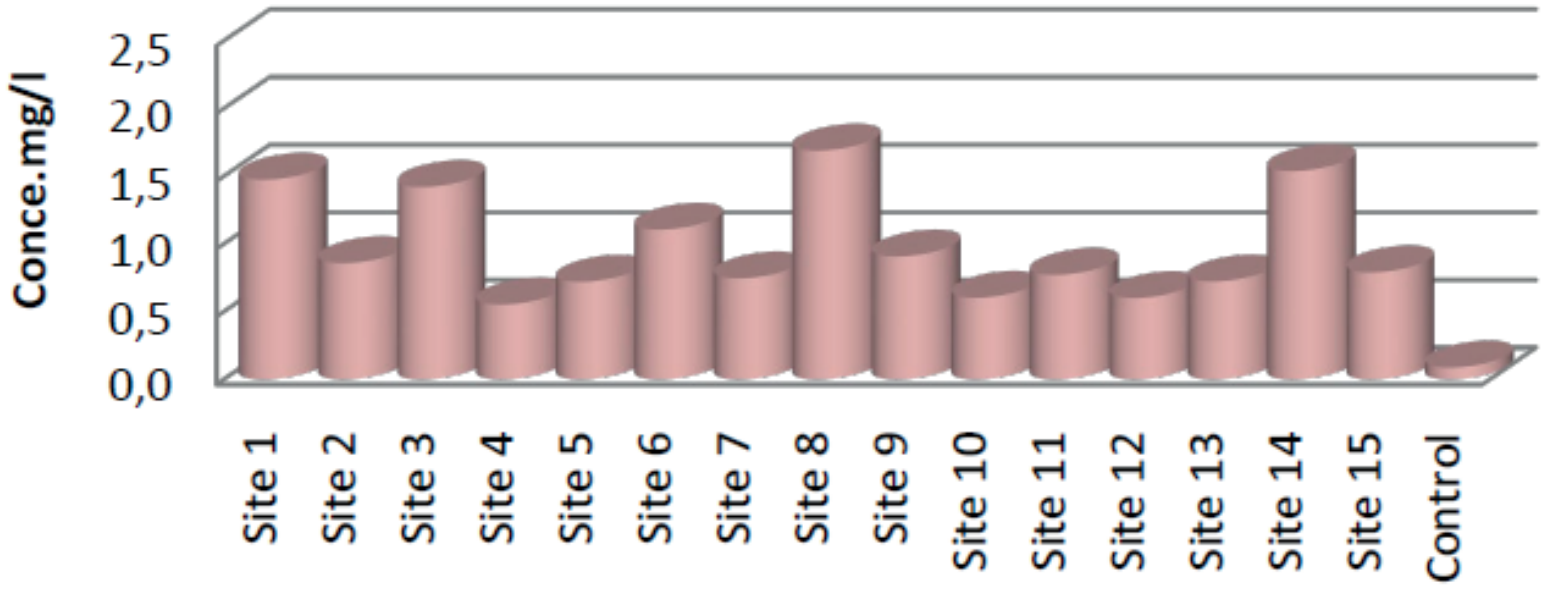

\section{Sites}

Figure 5. Shows the average concentration of phosphate ions in the samples.

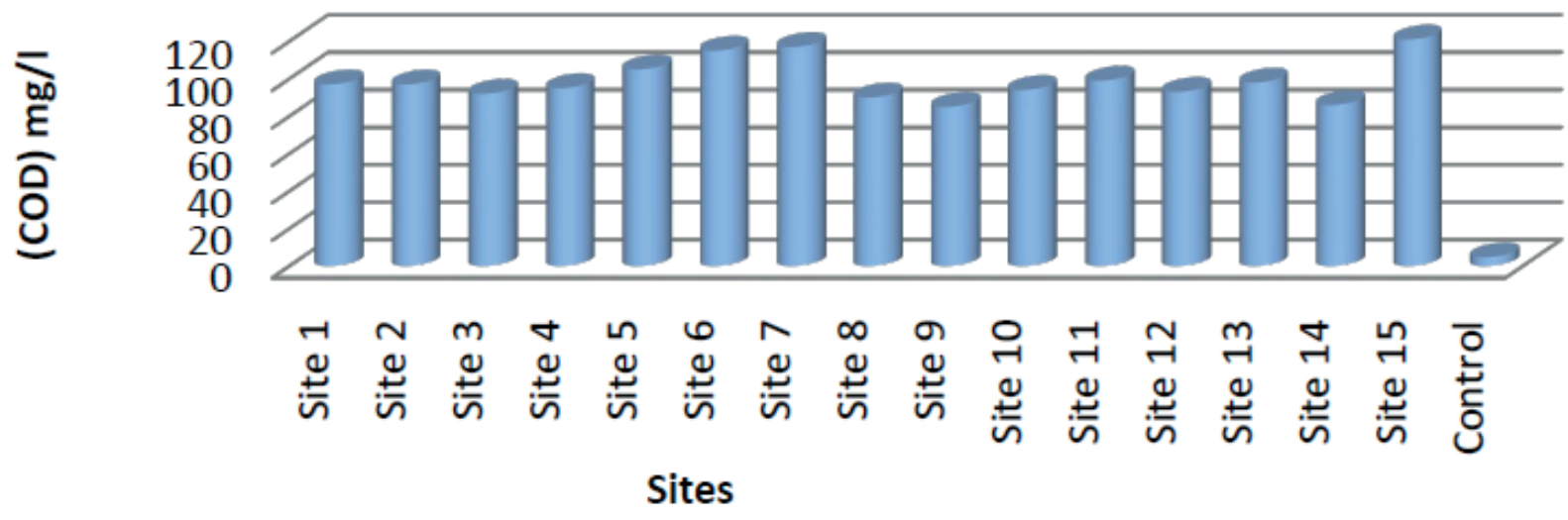

Figure 6. Shows the average C.O.D. concentration in the samples. 


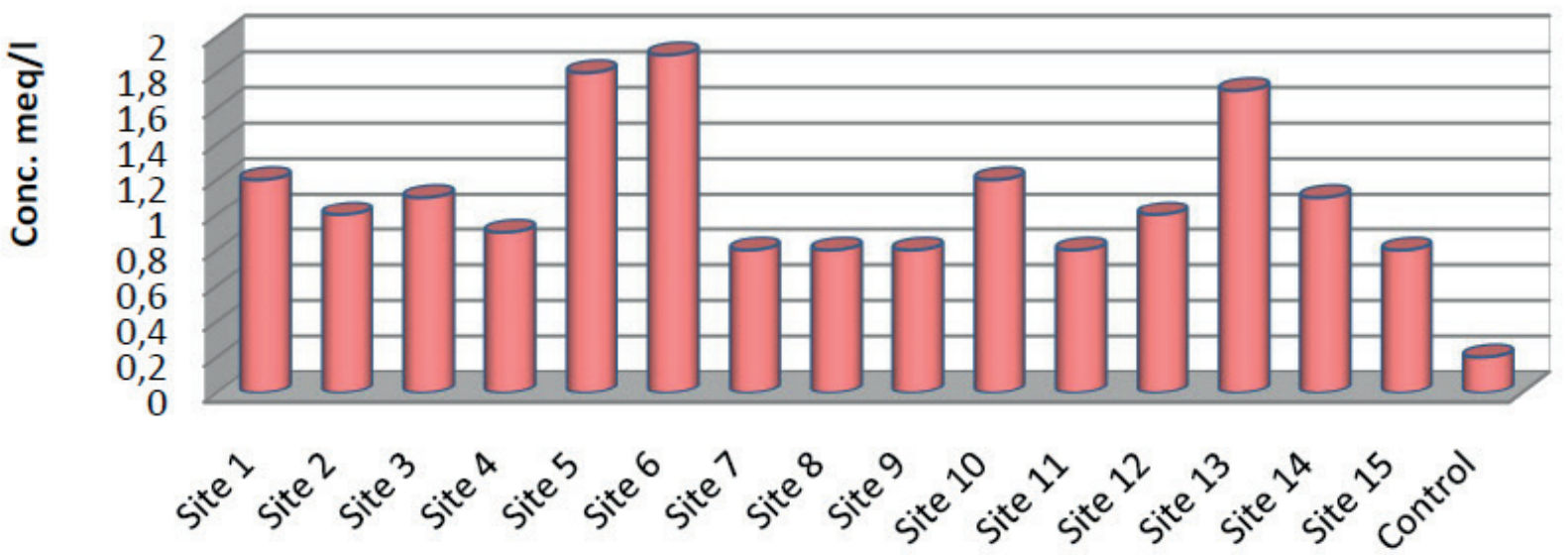

Sites

Figure 7. The average of S.A.R. for the water of the studied areas.

$\square$ Fecal Coliform

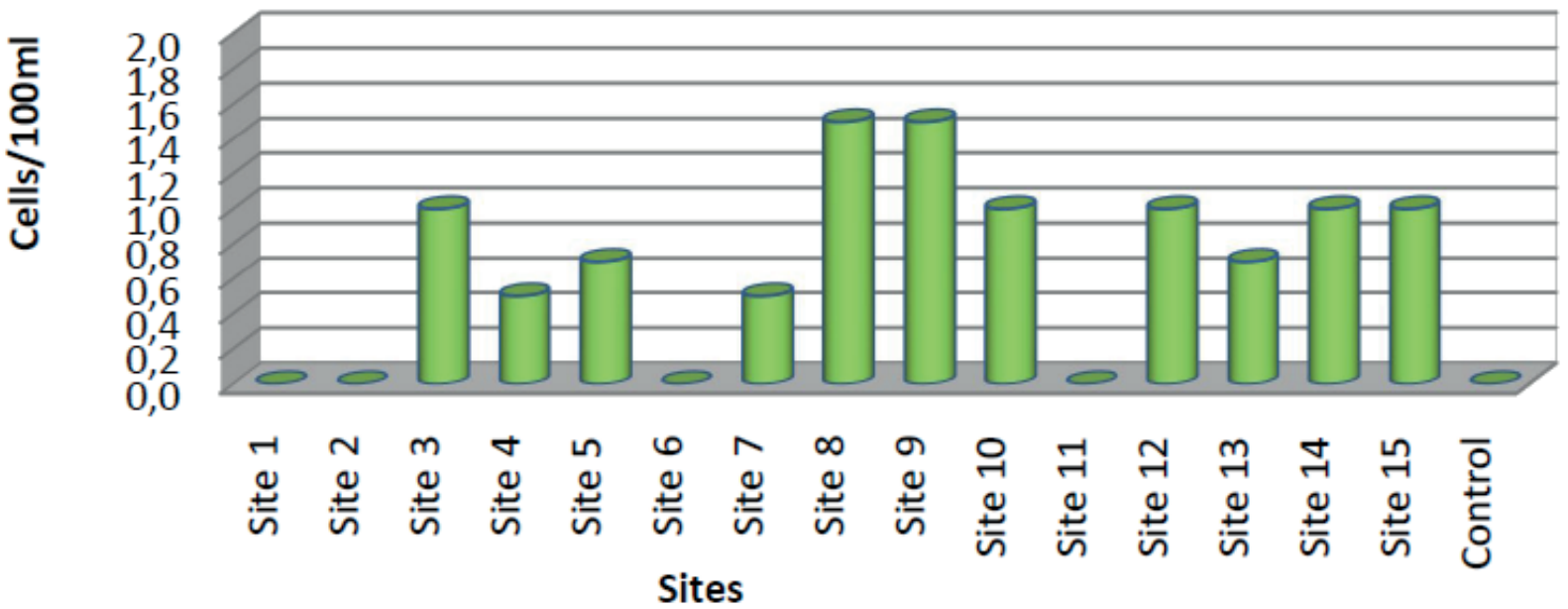

Figure 8. Shows the average number of fecal coliform bacteria in the cells of the sample $\times 10^{5} / 100 \mathrm{ml}$.

\section{Bibliographic references}

1. Al-Ansari N., Ali A.A., Knutsson S. Present Conditions and Future Challenges of Water Resources Problems in Iraq. Journal of Water Resource and Protection,2014; 6, 1066-1098.

2. Juma.A.I., AL-Shamary.S.H., Hassan.Z.A.,AL-Hadithy.A.H. Using of gray water and treated wastewater in irrigation and its effect on some soil properties and Cassia Fistula plant growth.3rd International Scientific Conference / College of Education for Girls / Al-Kufa University2018; 5-6/Dec.

3. Nolde, E. Greywater reuse systems for toilet flushing in multi-storey buildings-over ten years' experience in Berlin. Urban water,2000;1(4), 275-284.

4. Emmerson, G., \& Emmerson, G. Every drop is precious: Greywater as an alternative water source. Queensland Parliamentary Library Publications and Resources Section.1998;.

5. Water CASA,. Residential Greywater Reuse Study; Greywater Reuse Survey: Data \&Evaluation of results. Southern Arizona, USA.2003.

6. APHA, AWWA and WCPE . "Stand Method for Examination of water and wastewater American public Health Association,1998; 20th ed., Washington DC, U.S.A.
7. Gorgich, M., Mata, T. M., Martins, A., Caetano, N. S., \& Formigo, N. Application of domestic greywater for irrigating agricultural products: A brief study. Energy Reports,2020; 6, 811-817.

8. Ali, M. M., Ali, M. L., Islam, M. S., and Rahman, M. Z. Preliminary assessment of heavy metals in water and sediment of Karnaphuli River, Bangladesh. Environmental Nanotechnology, Monitoring \& Management,2016; 5: 27-35.

9. Morel, A. Greywater management in low and middle-income countries . Dubenforf, CH: Swiss Federal Institute of Aquatic Science and Technology.2006:囚(No.628.2 G842g)

10.Odipe, O. E., Sawyerr, H. O., and Adewoye, S. O. Filling Stations and Their Effects on Groundwater Quality in Ilorin Metropolis. International Journal of Environmental Protection and Policy,2020; 8(1): 11-22

11. Eriksson, E., Auffarth, K., Henze, M., \& Ledin, G. Characteristics of grey wastewater. Urban Water,2002; 4, 85-104.

12. Edwin, G. A., Gopalsamy, P., \& Muthu, N. Characterization of domestic gray water from point source to determine the potential for urban residential reuse: a short review. Applied Water Science, 2014; 4, 39-49.

13. Oteng-Peprah, M., Acheampong, M. A., \& DeVries, N. K. Greywater characteristics, treatment systems, reuse strategies and user perception-a review. Water, Air, \& Soil Pollution,2018; 229(8), 1-16.凶 
14. Rakesh, S. S., Ramesh, P. T., Murugaragavan, R., Avudainayagam, S., \& Karthikeyan, S. Characterization and treatment of grey water: A review. IJCS,2020; 8(1), 34-40.ख

15. Boyjoo, Y., Pareek, V. K., \& Ang, M. A review of greywater characteristics and treatment processes. Water Science and Technology, 2013; 67, 1403-1424.

16. Al-Fatlawi, A. H., \& Mohammed, B. Estimation and Characterization of Grey Water in Karbala City During 2018; 5: 24-37.

17. Aboukarima, A.M., Al-Sulaiman, M.A., El-Mazarky, M.S.A. Effect of S.A.R. and E.C. of the applied water on infiltration in a sandy-loam soil. WaterSA2018; 44 (1), 105-110.

18. Department of Environment and Resource Management (DERM). Available online,2009; (Accessed 22 June 2019),

19. Rashidi, M., Seilsepour, M., Modeling of soil exchangeable sodium percentage based on soil sodium adsorption ratio. J. Agric. Biol. Sci.2008; 3, 22-26.

20.Adejumo, R. O., Adagunodo, T. A., Bility, H., Lukman, A. F., and Isibor, P. O. Physicochemical constituents of groundwater and its quality in crystalline bedrock, Nigeria. International Journal of Civil Engineering and Technology (IJCIET),2018; 8(9): 887-903.

21. Nag, S. K. and Das, S. Quality Assessment of groundwater with Special emphasis on irrigation and domestic suitability in Suri I and II 883Blocks, Birbhum dstrict west Bengal, India. American Journal of Water Resources, 2014; 2(4): 81-98.

22. Okpashi, V. E., Efut, E. N., Agnes, E. A. O., and Uba, U. J. Biochemical and Bacteriological Assessment of Ground Water Quality: Associating Bacteria Uptake with Human Infectious Diseases. Health Sci J,2019; 13(1):1-9.

23. Jeon, D. J., Ligaray, M., Kim, M., Kim, G., Lee, G., Pachepsky, Y. and Cho, K. H. Evaluating the influence of climate change on the fate and transport of fecal coliform bacteria using the modified SWAT model. Science of the Total Environment,2019; 658, (25 March 2019) 753-762

24. Toole, J., Sinclair, M., Malawaraarachchi, M., Hamilton, A., Barker, S. F., \& Leder, K. Microbial quality assessment of household greywater. Water Research,2012; 46, 4301-4313.

25. Boyjoo, Y., Pareek, V. K., \& Ang, M. A review of greywater characteristics and treatment processes. Water Science and Technology,2013; 67, 1403-1424.

Received: 10 August 2021

Accepted: 21 September 2021 